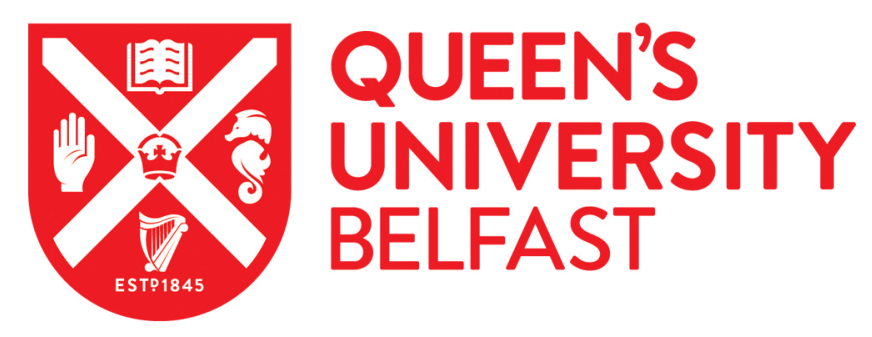

\title{
Correlation of light-off activity for full size and cored catalyst samples
}

Blades, L., Douglas, R., McCullough, G., \& Woods, A. (2016). Correlation of light-off activity for full size and cored catalyst samples. International Journal of Powertrains, 5(2), 148-166.

https://doi.org/10.1504/IJPT.2016.076567

\section{Published in:}

International Journal of Powertrains

\section{Document Version:}

Early version, also known as pre-print

\section{Queen's University Belfast - Research Portal:}

Link to publication record in Queen's University Belfast Research Portal

\section{Publisher rights}

(c) 2020 Inderscience Enterprises Ltd.This work is made available online in accordance with the publisher's policies. Please refer to any applicable terms of use of the publisher.

\section{General rights}

Copyright for the publications made accessible via the Queen's University Belfast Research Portal is retained by the author(s) and / or other copyright owners and it is a condition of accessing these publications that users recognise and abide by the legal requirements associated with these rights.

Take down policy

The Research Portal is Queen's institutional repository that provides access to Queen's research output. Every effort has been made to ensure that content in the Research Portal does not infringe any person's rights, or applicable UK laws. If you discover content in the Research Portal that you believe breaches copyright or violates any law, please contact openaccess@qub.ac.uk. 


\title{
Correlation of light-off activity for full size and cored catalyst samples
}

\section{Luke Blades*, Roy Douglas and Geoffrey McCullough}

School of Mechanical and Aerospace Engineering, Queen's University Belfast, UK

Email: lblades01@qub.ac.uk

Email: r.douglas@qub.ac.uk

Email: g.mccullough@qub.ac.uk

*Corresponding author

\section{Andrew Woods}

Catagen Limited,

5 Elmbank Channel, Commercial Park, Queen's Road,

Titanic Quarter, Belfast, BT3 9DT, UK

Email: andrew@catagen.co.uk

\begin{abstract}
This study identifies, and analyses, the correlation that exists in the CO light-off performance of full size canned catalytic converters and cored samples taken from the front and rear sections of the same catalyst brick. Testing was conducted under laboratory conditions, with full size samples tested using the Catagen Labcat, and testing of cored samples conducted using the Horiba SIGU 2000. From experimental tests alone, there was no clear correlation between the $\mathrm{CO}$ light-off activities of full size and cored catalyst samples. However, by performing simulations using the QUB global catalyst model, which accounts for the variation of precious metal dispersion and differences in the heat transfer characteristics of the test rigs, correlation was shown to be good.
\end{abstract}

Keywords: catalyst ageing; catalyst correlation; catalyst light-off; catalyst modelling; catalyst performance.

Reference to this paper should be made as follows: Blades, L., Douglas, R., McCullough, G. and Woods, A. (xxxx) 'Correlation of light-off activity for full size and cored catalyst samples', Int. J. Powertrains, Vol. X, No. Y, pp.xxx-Xxx.

Biographical notes: Luke Blades is a Post-Doctoral Researcher, working in the Clean Energies Research Cluster at Queen's University Belfast. He graduated with a MEng in Aerospace Engineering from Queen's University Belfast in 2010. He continued his studies at the same institution, earning a $\mathrm{PhD}$ in Mechanical Engineering for his work in the area of three-way catalyst ageing in 2015. During this work, he investigated the change in catalyst activity due to static and dynamic ageing, and used mathematical catalyst modelling to identify correlation between full size bricks and cored catalyst samples. His other research areas of interest include waste heat recovery. 
Roy Douglas is a Professor of IC Engines Technology and Director of Clean Energy Research in Mechanical Engineering at Queen's University, Belfast. He has over 35 years experience in the areas of engine research and development, systems modelling and automotive after-treatment. For the past ten years, his research has concentrated on automotive drive cycles and systems energy management, with particular emphasis on bus applications such as hybrid electric vehicles and thermal management of heavy duty powertrains. $\mathrm{He}$ is a senior member of the School of Mechanical and Aerospace Engineering and a member of the management board.

Geoffrey McCullough is a Senior Lecturer at Queen's University Belfast. He completed his PhD degree in 1997 on the subject of reaction kinetics within automotive catalysts. The main focus of his research is the reduction of emissions from automotive engines, which includes theoretical model development combined with experimental validation. He has published 65 papers in peer-reviewed journals and international conferences on this subject. He is an academic partner of the Centre for the Theory and Application of Catalysis (CenTACat) and teaches the internal combustion engines courses on both the Bachelors and Masters degree programs.

Andrew Woods is the CEO and co-founder of Catagen. He received both his Masters and PhD in Mechanical Engineering from Queen's University Belfast. His $\mathrm{PhD}$ degree (ageing and characterisation of automotive catalysts) culminated in the co-development of the original prototype that evolved into Catagen's product range. He holds two patents as co-inventor, one of which protects the innovation in the Catagen products. He, co-author on a number of papers, continues research within the Catagen organisation, making regular discoveries related to after treatment system development. $\mathrm{He}$ is extensively travelled and has participated in entrepreneurship training programs, the most notable of which was in Stanford University.

This paper is a revised and expanded version of a paper entitled 'Correlation of light-off activity for full size and cored catalyst samples' presented at the 1st Biannual International Conference on Powertrain Modelling and Control, Testing, Mapping and Calibration, University of Bradford, Yorkshire, UK, 4-6 September 2012.

\section{Introduction}

Regulations concerning automotive exhaust emissions are becoming more and more stringent, requiring the development of more efficient and durable catalytic control systems. The three-way catalytic converter is the most common method of reducing harmful exhaust gas emissions, by performing the simultaneous oxidation of carbon monoxide $(\mathrm{CO})$ and hydrocarbons $(\mathrm{HC})$, and reduction of oxides of nitrogen $\left(\mathrm{NO}_{\mathrm{x}}\right)$. A three-way catalyst has a honey-comb like, monolithic structure, and is usually made from a synthetic cordierite ceramic material. The monolith has uniformly sized, parallel channels, onto which the washcoat is bonded. Alumina, $\mathrm{Al}_{2} \mathrm{O}_{3}$, is the most commonly used washcoat as it has a very complex pore structure, providing a large surface area onto which the catalytic material is finely dispersed. The catalytic material is usually platinum $(\mathrm{Pt})$, palladium $(\mathrm{Pd})$ or rhodium $(\mathrm{Rh})$, and these precious metals may be used individually or in combination. Commercially used three-way catalysts are often a bimetallic 
combination of precious metals, such as $\mathrm{Pt} / \mathrm{Rh}$ or $\mathrm{Pd} / \mathrm{Rh}$, as rhodium is known to be an efficient catalyst for $\mathrm{NO}_{\mathrm{x}}$ reduction, whereas platinum and palladium are effective catalysts for the oxidation of carbon monoxide and hydrocarbons (Aitani and Siddiqui, 1995; Gandhi et al., 2003).

Thermal ageing is one of the primary causes of catalyst deactivation, and has become an increasingly important factor due to the converter being installed close to the engine for more efficient hydrocarbon conversion. Exothermic reactions can cause temperatures within the catalyst reaching higher than $1,000^{\circ} \mathrm{C}$, causing thermal deactivation such as sintering of the precious metal particles. At high temperatures, the precious metal particles agglomerate, decreasing the surface area of catalyst available to reactant gases and therefore reducing the catalyst activity (Harris, 1995; Heck et al., 2002; Martin et al., 2003; Martinez-Arias et al., 2002; Meyer Fernandes et al., 2010; Polvinen et al., 2004; Tanabe et al., 2008; Winkler et al., 2010; Yang et al., 2008; Zanon Zotin et al., 2005). Sintering of the washcoat can also occur, with a decrease in surface area and a loss of internal pore structure. The washcoat undergoes irreversible phase changes, with the alumina washcoat transforming from the gamma phase, $\gamma-\mathrm{Al}_{2} \mathrm{O}_{3}$, through delta, $\delta-\mathrm{Al}_{2} \mathrm{O}_{3}$ and theta, $\theta-\mathrm{Al}_{2} \mathrm{O}_{3}$, to the stable alpha alumina, $\alpha-\mathrm{Al}_{2} \mathrm{O}_{3}$, with loss of surface area and hence loss of catalyst activity (Heck et al., 2002; Martinez-Arias et al., 2002; Meyer Fernandes et al., 2010; More et al., 1997; Zanon Zotin et al., 2005). Catalyst deactivation can also be caused by catalyst poisoning, which can occur by two mechanisms. Selective poisoning is the mechanism by which an undesirable contaminant reacts directly with the precious metal or washcoat, and non-selective poisoning, by masking or fouling, occurs when a heavy contaminant is deposited onto the catalytic surface. Poisoning results in a reduced number of active sites available to the reactant gases and therefore causes reduced catalyst activity (Heck et al., 2002; Zanon Zotin et al., 2005). Another form of catalyst deactivation is mechanical deactivation, were the decrease in catalytic activity is caused by loss of catalyst material due to fractures in the ceramic monolith (Zanon Zotin et al., 2005).

A study of the literature has shown that much research has been conducted, which involves the laboratory analysis of engine aged catalyst samples. Catalyst light-off is regularly used to indicate the activity level of an automotive catalyst and is defined as the temperature of $50 \%$ conversion, of $\mathrm{CO}, \mathrm{HC}$ or $\mathrm{NO}_{\mathrm{x}}$. Smelder et al. (1991) carried out activity tests, in a synthetic exhaust flow reactor system, on catalyst samples taken from various locations of full size field aged catalysts. Light-off tests showed how deactivation by thermal effects followed a radial profile, with major deactivation occurring at the centre of a cylindrical catalyst brick and decreasing outwards towards the edges. Martin et al. (2003) analysed catalyst samples taken from an automobile aged catalyst in order to measure the axial deterioration. This study concluded that poisoning had a low influence on ageing and that deactivation is mainly produced by thermal mechanisms. A similar study was carried out by Lopez Granados et al. (2006), which analysed samples taken from different axial coordinates of three-way catalyst monoliths aged under real life traffic conditions. This research showed that the front and rear catalyst samples were aged to a similar deactivated state. Loss of specific surface due to sintering of washcoat components was found to be present throughout the catalyst. Research conducted by Zanon Zotin et al. (2005) showed that the deactivation of catalyst samples, aged on an engine bench, was not due to one factor, but a combination of thermal, chemical and mechanical deactivation. A study by Meyer Fernandes et al. (2008) showed that thermal 
effects were the major contributor to catalyst deactivation. CO light-off tests conducted on samples aged on a chassis dynamometer showed that the loss of activity was consistent with the decrease in BET surface area. Lassi (2003) showed that for ageing on an engine test bench, thermal deactivation mechanisms were important. These included sintering of the precious metal active sites, loss of washcoat surface area and phase transitions. Moldovan et al. (2003) showed that, after automobile ageing, the loss of precious metal particles, and therefore a reduction in dispersion, was much greater at the front face of a three-way catalyst than in any other region of the brick. A study by Harkönen et al. (1994) showed that for engine and on-road ageing, the highest deactivation occurred at the front zone of a catalyst. Engine ageing followed by laboratory analysis has also been conducted by Usmen et al. (1992), Zhang et al. (1997), Hughes (2005), Kallinen et al. (2005), He et al. (2003) and Hietikko et al. (2004).

In the literature, there are many examples of work which conducts laboratory analysis of catalyst cores or cuttings. However, there are no published results of laboratory analysis on full size commercial catalysts. This study analyses the effect that engine ageing has on a full size catalyst brick, and then compares the results with cored size samples taken from these bricks. No studies have been published that attempt to correlate the activity of full size and cored catalyst samples. The successful correlation of full size and cored samples is the main aim of this paper. It is important to understand if correlation does exist, as studies such as that conducted by Dubien et al. (1998), have used light-off results from cored samples to develop reaction kinetics for catalyst models. In the study carried out by Dubien, the kinetics developed from laboratory tests did not correlate well with engine kinetics.

\section{Experimental}

Four commercial three-way catalysts were used throughout this study. The cylindrical ceramic cordierite monoliths had a volume of 1 litre (103 mm diameter, $130 \mathrm{~mm}$ length) and a cell density of 400 channels per square inch. The alumina washcoat was loaded with a combination of Pd and Rh precious metals. Each of the catalysts were obtained after engine ageing had been conducted for 100 hours, however, further details of the engine ageing procedure are unknown as the ageing was performed by an outside company. The full size catalysts used throughout this study are referred to as Catalysts 1, 2, 3 and 4. CO light-off activity tests were conducted for each of the full size catalysts using the Catagen Labcat, and for a range of cores taken from these bricks using the Horiba SIGU 2000, in order to analyse the effects that engine ageing had on the catalyst activity and to identify if correlation exists between the testing methods.

The Labcat is a highly innovative dynamic, catalytic ageing and evaluation system, which artificially creates exhaust gas composition and temperature using computer controlled synthetic gases (Catagen Ltd., 2013). The simulated exhaust gas passes through an infrared tube furnace, which heats the gas to a predefined temperature and then through the catalyst brick. Each of the four canned catalyst samples were mounted in the interchangeable sample manifold, with thermocouples located both upstream and downstream of the catalyst brick, as well as two thermocouples probing into the centre of the catalyst bed at $1 / 3$ and $2 / 3$ the height of the brick, as shown in Figure 2 . Inlet gas concentrations were measured using the Horiba MEXA-584L portable automotive 
emission analyser, while outlet gas concentrations were measured using the Horiba MEXA-7000.

$\mathrm{CO}$ light-off tests were conducted for full size bricks in the Labcat at a space velocity of $55,000 \mathrm{hr}^{-1}$, and inlet gas concentrations of; $\mathrm{CO}_{2}-10 \%, \mathrm{O}_{2}-1 \%, \mathrm{CO}-0.5 \%$, $\mathrm{N}_{2}$ - balance. For each test in the Labcat, the sample was stabilised at a temperature of $150^{\circ} \mathrm{C}$ before applying the light-off ramp. During the light-off ramp, the inlet gas stream temperature was increased to a maximum of $300^{\circ} \mathrm{C}$ at a rate of $25^{\circ} \mathrm{C} / \mathrm{min}$. The temperature/time graph is shown in Figure 3.

Figure 1 Catagen Labcat (see online version for colours)



Source: Catagen Ltd. (2013)

Figure 2 Labcat canned catalyst installation (see online version for colours)

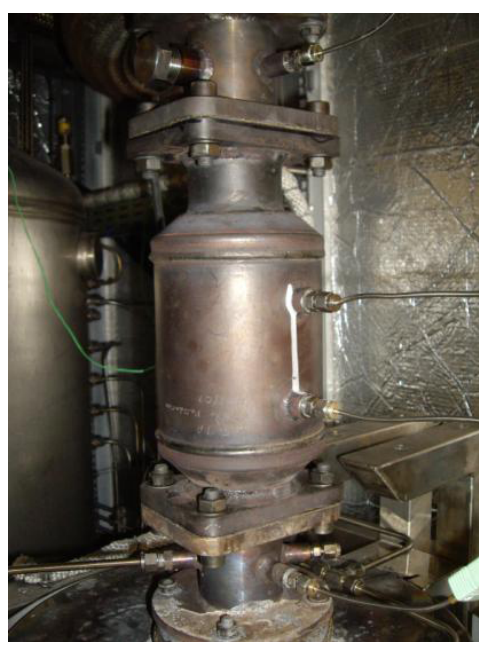


CO light-off tests were also performed on the Horiba SIGU 2000, which generates a simulated exhaust gas mixture from a series of gas bottles. Both the Horiba MEXA-7000 and the Horiba MEXA-6000 FTIR exhaust gas analysers were used to measure the gas concentrations. Results obtained from the MEXA-7000 were used to compare the SIGU tests to the Labcat tests. The FTIR results were used to confirm the accuracy of the MEXA-7000 results and also to monitor the $\mathrm{O}_{2}$ concentration throughout the tests. The SIGU is not capable of testing commercial full size catalyst bricks and therefore cored samples must be taken from these and tested individually. The Horiba SIGU 2000 is shown in Figure 4.

Figure 3 Labcat temperature - time graph for CO light-off test (see online version for colours)

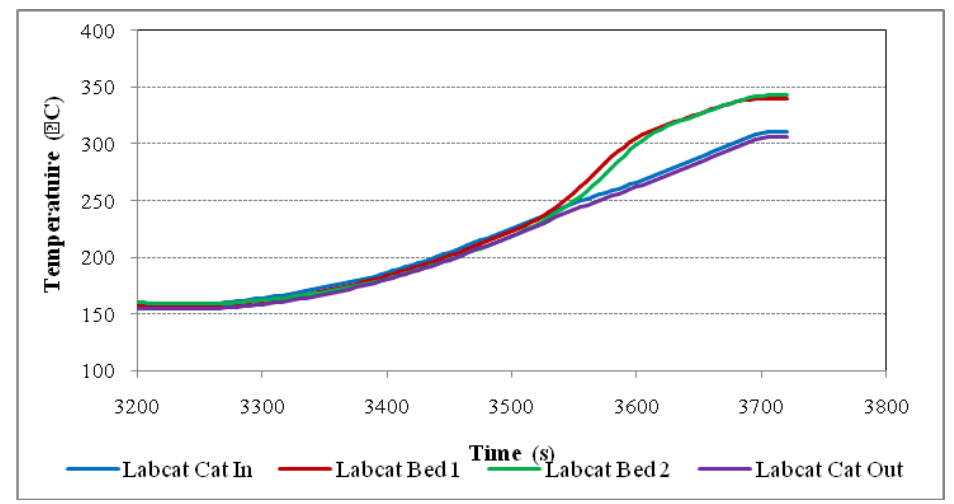

Figure 4 Horiba SIGU 2000 (see online version for colours)




Figure 5 SIGU cored catalyst installation (see online version for colours)

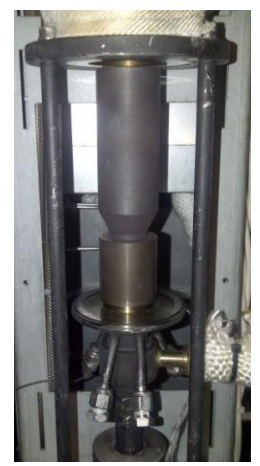

For each of the four catalysts, a $36 \mathrm{~mm}$ diameter cylindrical core was cut from the centre of the catalyst bricks, all the way through from the front face to the rear. Samples of $36 \mathrm{~mm}$ length were then taken from the front and rear of these centre cores and labelled $\mathrm{CF}$ and $\mathrm{CR}$ respectively. The labelling scheme used for the samples was by brick number $(1,2,3$ or 4 ) and by position (front CF or rear CR). For example, 1CF is the core taken from the front of brick 1 and $3 \mathrm{CR}$ is the core taken from the rear of brick 3 .

The CO light-off tests were performed on the SIGU with the following gas concentrations at the catalyst inlet; $\mathrm{CO}_{2}-10 \%, \mathrm{O}_{2}-1 \%, \mathrm{CO}-0.5 \%, \mathrm{H}_{2} \mathrm{O}-5 \%$, $\mathrm{N}_{2}$ - balance. Before conducting each light-off test, a flow check was conducted at $100^{\circ} \mathrm{CC}$, with no sample in the reactor, so that the flow rate of each gas species could be adjusted in order to achieve the required gas concentrations. A space velocity of $55,000 \mathrm{hr}^{-1}$ was used for each test, creating a gas flow similar to that used in the Labcat tests. Figure 6 shows the temperature profile used for each of the cored samples tested in the SIGU. In the SIGU, only the catalyst inlet and outlet temperatures are measured, as it is difficult to measure the catalyst bed temperature without interfering with the flow through the small samples.

Figure 6 SIGU CO light-off test temperature profile (see online version for colours)

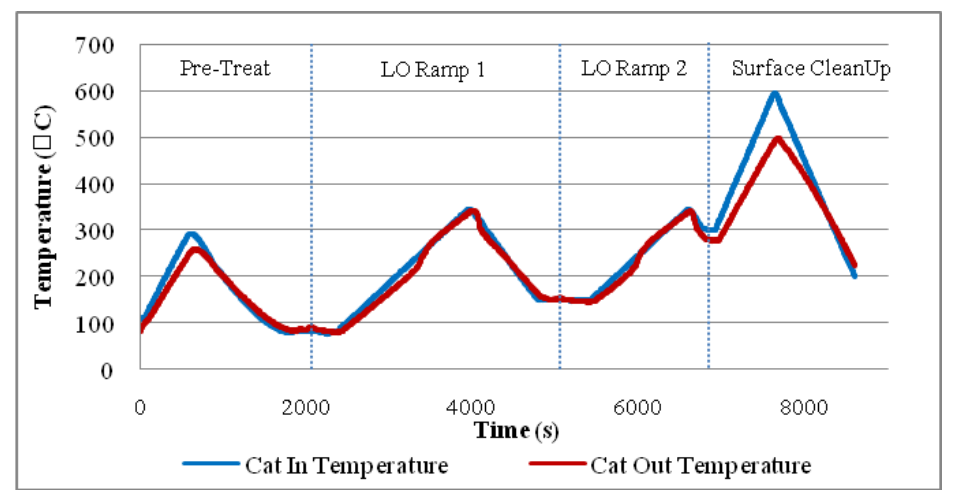

At least three repetitions of the light-off tests were conducted for each catalyst sample. To ensure that the catalyst surface was in a similar state at the beginning of each test a 
'surface clean up' in nitrogen was carried out after the light-off ramps, using a profile of $25^{\circ} \mathrm{C} / \mathrm{min}$ up to $600^{\circ} \mathrm{C}$, similar to the pre-treatment procedure suggested by McAtee et al. (2004). Also, at the beginning of each test, the catalyst was pre-treated in nitrogen at $20^{\circ} \mathrm{C} / \mathrm{min}$ up to $300^{\circ} \mathrm{C}$, to 'clean' the surface. After the pre-treatment, the catalyst was stabilised at $80^{\circ} \mathrm{C}$ before introducing the exhaust gases. A sample of the exhaust gas at the catalyst inlet was taken over a five minute period at a constant temperature of $80^{\circ} \mathrm{C}$, and an average taken, in order to find an accurate concentration for each of the exhaust gas species. For the first light-off ramp, the temperature was then ramped at $10^{\circ} \mathrm{C} / \mathrm{min}$ up to a maximum temperature of $350^{\circ} \mathrm{C}$, which is sufficient for $100 \%$ conversion of the inlet $\mathrm{CO}$ gas. A second light-off ramp was then completed, starting from a temperature of $150^{\circ} \mathrm{C}$, at a rate of $10^{\circ} \mathrm{C} / \mathrm{min}$ up to a maximum temperature of $350^{\circ} \mathrm{C}$. At the top of each light-off ramp, the exhaust gases were switched off and after the second ramp the catalyst was allowed to cool in nitrogen to $300^{\circ} \mathrm{C}$ before the post light-off 'surface clean up' begins. The light-off temperatures obtained on the second light-off ramp, following the $150^{\circ} \mathrm{C}$ stabilisation, were used to compare the performance of the cored samples to the full size bricks as this temperature profile best matches that used in Labcat light-off ramp.

\section{QUB global catalyst model}

The QUB global catalyst model was first developed by McCullough (1997) as a Fortran code and has been considerably enhanced as a Microsoft Excel VBA based model over the past few years. The current version is described by Stewart et al. (2012). Inputs to be specified include catalyst and housing geometry, precious metal loading and dispersion, material properties, mesh density, reaction and activation energies, pre-exponential constants and inhibition terms. The model simulates the catalyst activity based on these parameters.

The model has been developed for 18 reactions (Stewart et al., 2102), which represent the full set of reactions that typically occur in a three-way automotive catalyst. These reactions can be classified under three headings; oxidation reactions, water-gas and steam reforming and the oxides of nitrogen $\left(\mathrm{NO}_{\mathrm{x}}\right)$ reactions. In the model, these reactions can be switched on or off depending on the gas species that exist in the simulated exhaust flow. The reaction equations are based on the Langmuir-Hinshelwood approach as proposed by Voltz et al. (1973) and later modified by Oh and Eickel (1988). Activity is calculated by an Arrhenius promoting term that depends on gas phase concentration and precious metal active surface area, which is directly related to the precious metal dispersion. Inhibition depends on the gas-phase concentrations of carbon monoxide, hydrocarbons and oxides of nitrogen.

The model uses standard diffusion theory to model the mass transfer of the reacting gases to the surface, and the transfer rate of gases is determined from Fick's law. Heat transfer in the model uses the laws of conduction and convection. Fourier's law is used to calculate the solid state conduction and limiting Nusselt number, with Newton's law of convection used to determine the convection heat transfer between the solid and gas.

The catalyst mesh defines the profile of the catalyst, with the catalyst monolith, matting and steel casing all included. The mesh considers elements in both the axial and radial direction. 


\section{Results and discussion}

CO light-off tests were performed for each of the canned full size catalysts on the Labcat. The light-off curves produced are shown in Figure 7. The light-off temperature illustrates the activity of the catalyst, with a lower light-off temperature indicating a greater activity than a sample with a higher light-off temperature. These results show that Catalyst 1 was the most active with a light-off at $221^{\circ} \mathrm{C}$, followed by Catalyst $2,225^{\circ} \mathrm{C}$, Catalyst 4 , $234^{\circ} \mathrm{C}$, and Catalyst $3,251^{\circ} \mathrm{C}$. The $100 \%$ conversion points also follow a similar trend with Catalyst 1 at $235^{\circ} \mathrm{C}$, followed by Catalyst $2,244^{\circ} \mathrm{C}$, Catalyst $4,257^{\circ} \mathrm{C}$, and Catalyst $3,272^{\circ} \mathrm{C}$, indicating that Catalyst 1 is the most active and Catalyst 3 the least active.

Each of the four catalysts were engine aged for 100 hours under the same conditions and would therefore be expected to show similar levels of activity, however, Figure 7 shows that considerable variability exists. CO light-off activity for Catalysts 1 and 2 are fairly similar but light-off temperatures for Catalyst 4 is more than $10^{\circ} \mathrm{C}$ higher than Catalyst 1 , and Catalyst 3 is $30^{\circ} \mathrm{C}$ higher. It is clear that variation exists between the full-sized bricks, even though they are all of the same formulation, from the same manufacturer, and all engine aged to the same level. This variation could be due to the engine ageing process or brick-to-brick variation. This could be due to flow or temperature variation during engine ageing, however, as the engine ageing data is not available it is difficult to be definitive. $\mathrm{CO}$ activity tests on cored samples from different axial locations within each full size sample could help to identify the source of this variability.

Figure 7 CO light-off curves for Labcat tested full size catalysts (see online version for colours)



The CO light-off curves for the cored samples, taken from the centre of each full sized catalyst and tested on the Horiba SIGU 2000, are plotted in Figures 8, 9, 10 and 11 for Catalysts 1, 2, 3 and 4, respectively. The light-off curves for both the front and rear cores are plotted, along with the Labcat test for the corresponding full size catalyst brick. Table 1 presents the CO light-off temperatures for each full size brick and the cored samples. 
Table 1 CO light-off temperatures for cored samples

\begin{tabular}{lccc}
\hline & Front core & Rear core & Full sample \\
\hline Catalyst 1 & $238^{\circ} \mathrm{C}$ & $244^{\circ} \mathrm{C}$ & $221^{\circ} \mathrm{C}$ \\
Catalyst 2 & $243^{\circ} \mathrm{C}$ & $240^{\circ} \mathrm{C}$ & $225^{\circ} \mathrm{C}$ \\
Catalyst 3 & $244^{\circ} \mathrm{C}$ & $235^{\circ} \mathrm{C}$ & $251^{\circ} \mathrm{C}$ \\
Catalyst 4 & $238^{\circ} \mathrm{C}$ & $245^{\circ} \mathrm{C}$ & $234^{\circ} \mathrm{C}$ \\
\hline
\end{tabular}

Figure 8 CO light-off curves for SIGU and Labcat tests for Catalyst 1 (see online version for colours)

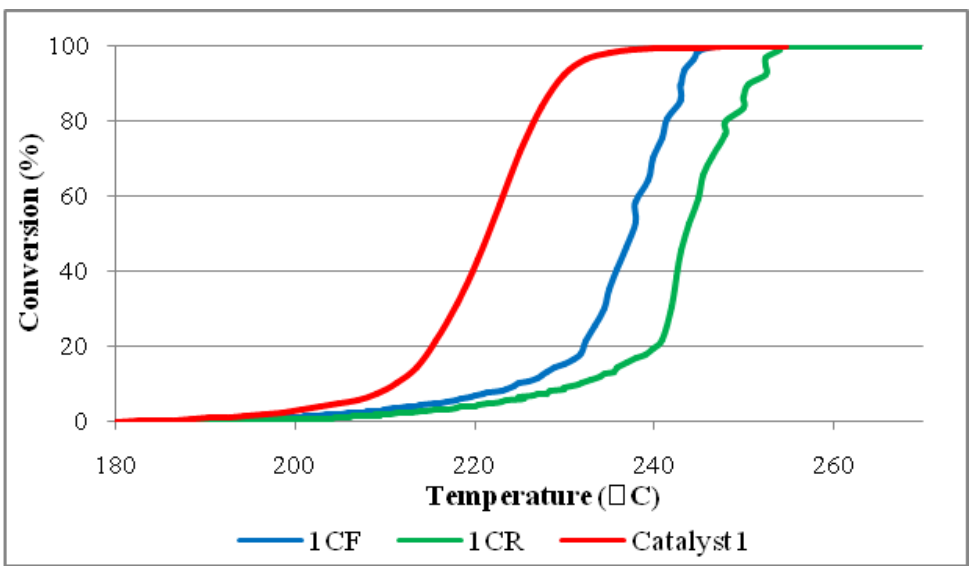

Figure 9 CO light-off curves for SIGU and Labcat tests for Catalyst 2 (see online version for colours)

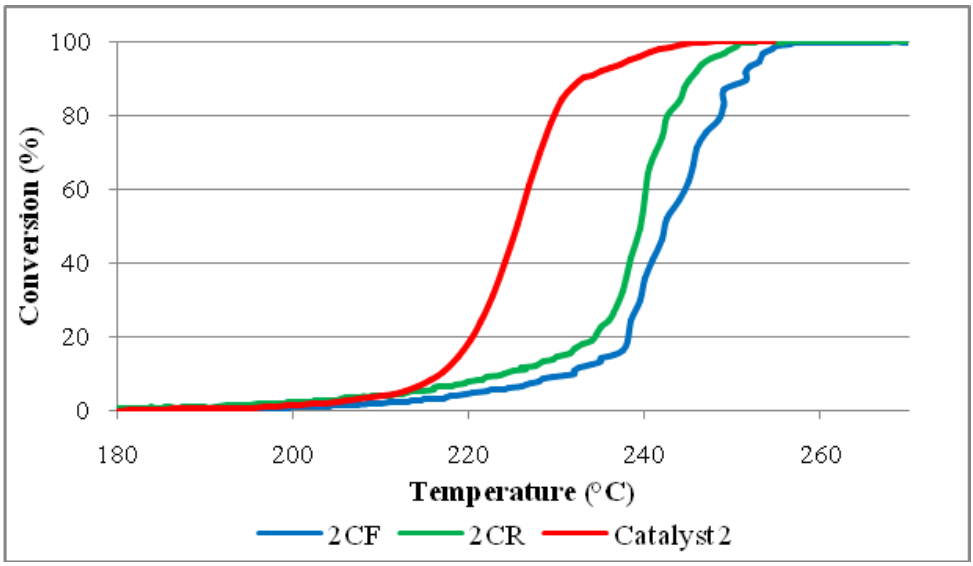


Figure 10 CO light-off curves for SIGU and Labcat tests for Catalyst 3 (see online version for colours)

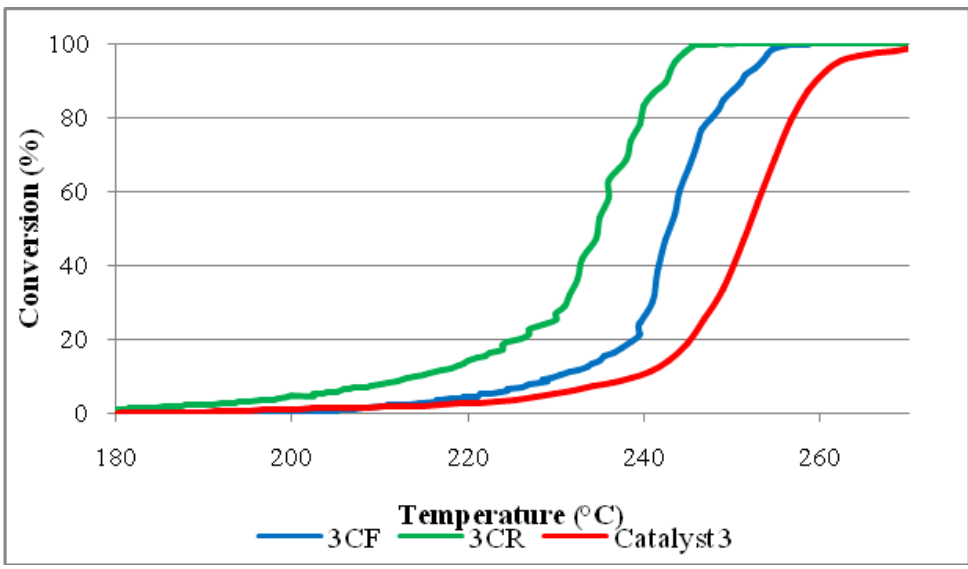

Figure 11 CO light-off curves for SIGU and Labcat tests for Catalyst 4 (see online version for colours)

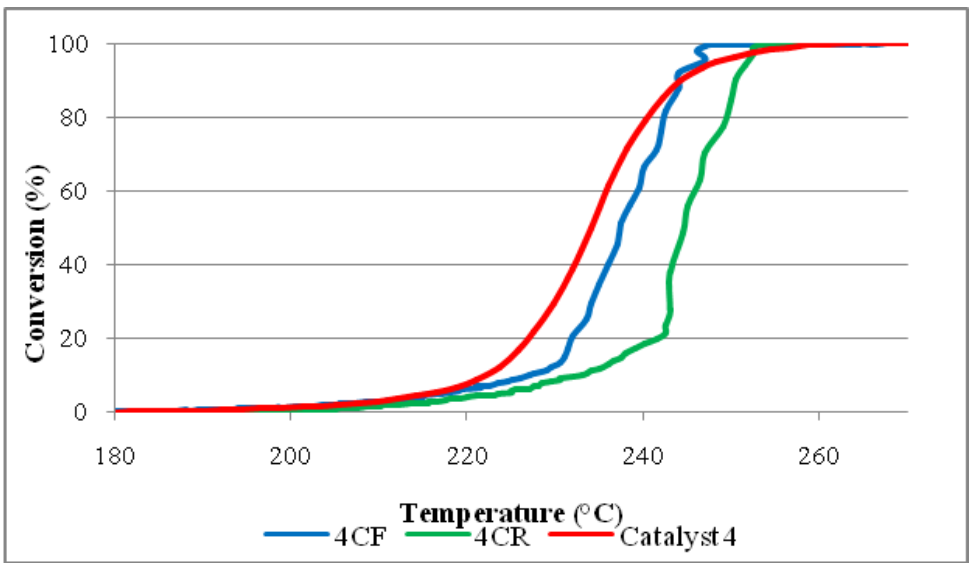

It can be seen from the SIGU tests that some variation exists throughout each individual full size catalyst brick. For example, Catalysts 2 and 3 show slightly better activity at the rear of the brick than at the front, which may suggest greater degradation of the catalyst at the front face due to thermal deactivation. However, this trend does not exist for Catalysts 1 and 4 which show the opposite with greater light-off activity for the cores taken from the front of the brick. Light-off temperatures vary by only $10^{\circ} \mathrm{C}$ for all the cores tested.

The differences between the cores and the full samples give an indication of the variation within a full catalyst brick. This is shown by small differences in the light-off temperatures of the cores. For Catalyst 4 , the full brick lights-off only $4^{\circ} \mathrm{C}$ earlier than the front core, however for Catalyst 2 the difference is $18^{\circ} \mathrm{C}$. Differences between cored samples and full size catalyst light-off performance may be due to thermal ageing, which 
may vary in the axial and radial directions throughout the brick, however, no trends were seen to prove this. Another important parameter may be a variation in the precious metal dispersion, resulting in some areas of the brick having more catalyst active sites and higher activity. The QUB global catalyst model will be used in this study to give an estimate of the precious metal dispersion for each catalyst sample.

It is difficult to see from the experimental tests alone if good correlation exists between the light-off performance of a full size catalyst and its corresponding cored samples. Also, the different heat transfer characteristics of the Labcat and the SIGU cannot be assessed from light-off tests. Each CO light-off test, for both the Labcat and the SIGU, were therefore simulated using the QUB global catalyst model to examine more closely if correlation does exist between cored samples and full size catalyst bricks. Of the

18 reactions modelled, only the oxidation of carbon monoxide was considered in the simulations. For each $\mathrm{CO}$ light-off test, the catalyst inlet temperature and gas concentration profile, at 5 second intervals, were used as inputs to the model and a simulation performed to generate outlet temperature and gas concentration profiles. As the inlet and outlet gas concentrations are known on completion of the simulation, as well as the catalyst inlet and outlet temperatures at each time step, the $\mathrm{CO}$ conversion and light-off temperature can be calculated. The heat transfer factor, $B$, is used to calculate the convection heat transfer coefficient, $h$, and therefore the external heat transfer. Equation (1) shows how the heat transfer factor is incorporated into the model, in the natural convection equation (Awbi, 1998; Siminson, 1988), which is used to calculate the heat loss from the steel shell around the catalyst to the surrounding air. For each simulation, the value of $\mathrm{B}$ is adjusted to match the temperature profile of the experimental test.

$$
h=B\left[\left(T_{\text {steel }}-T_{\text {atmos }}\right) / d\right]^{-0.25}
$$

where $h$ is the convection heat transfer coefficient $\left(\mathrm{W} / \mathrm{m}^{2} \mathrm{~K}\right), B$ is the heat transfer factor, $T_{\text {steel }}$ is the temperature of the steel shell $(\mathrm{K}), T_{\text {atmos }}$ is the temperature of the surrounding air $(\mathrm{K})$ and $d$ is the outer diameter of the steel shell (m).

Figure 12 Temperature profile for sample 1CF (see online version for colours)

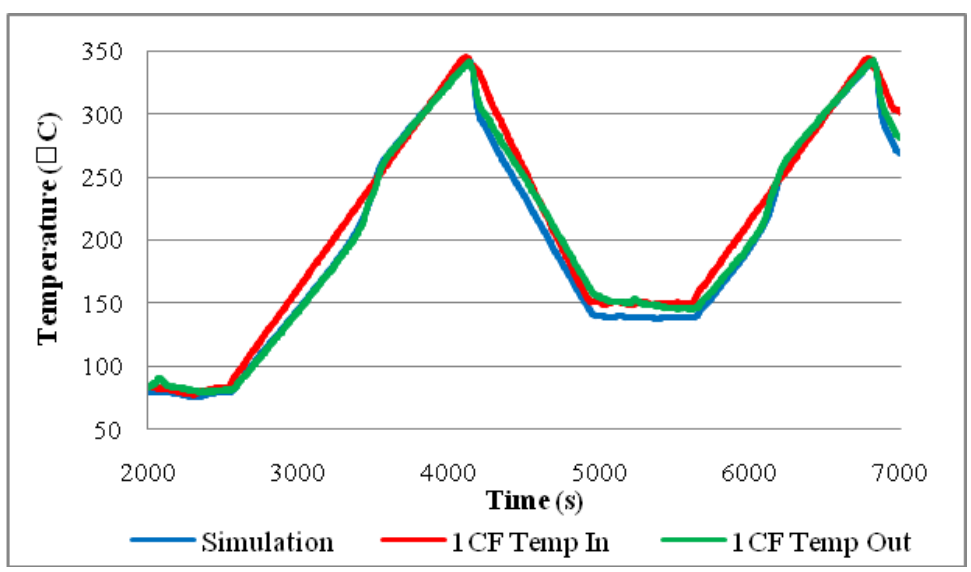


The precious metal dispersion percentage is also altered to match the catalyst outlet $\mathrm{CO}$ concentration of the simulation with that of the test. An example of the matched temperature and $\mathrm{CO}$ concentration profile for sample $1 \mathrm{CF}$ are shown in Figures 12 and 13, respectively. The matched temperature and $\mathrm{CO}$ concentration profiles for the Catalyst 1 full size brick are shown in Figures 14 and 15, respectively. The values of dispersion percentage and heat transfer factor required to match the simulation results with the experimental test results are shown in Table 2.

For the full size catalysts, the simulation results show that a variation exists in the precious metal dispersion percentage that is required to match the $\mathrm{CO}$ concentration profiles of the simulations with those of the experimental light-off tests. As expected, Catalyst 1, which was the most active catalyst with the lowest light-off temperature was found using the model to have the greatest dispersion of precious metals. The model showed that the catalyst with the lowest precious metal dispersion was Catalyst 3 . Catalyst 3 was shown to be the catalyst with the highest light-off temperature and was therefore the least active. The external heat transfer factor required to match the catalyst outlet temperature profiles of the simulations to those of the experimental tests were identical for each of the full size catalysts tested in the Labcat. The external heat transfer factor relates to the test rig used to conduct the tests, and as this was the same for each of the full size catalyst tests it was expected that this value would be the same for each simulation.

Figure $13 \mathrm{CO}$ concentration profile for sample 1CF, light-off ramp 2 (see online version for colours)

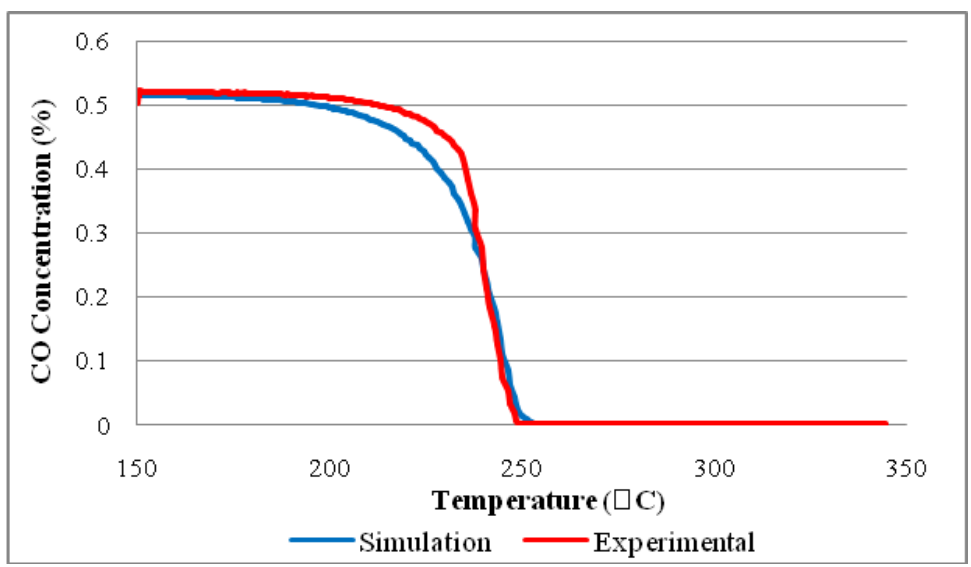


Figure 14 Temperature profile for Catalyst 1 (see online version for colours)



Figure 15 CO concentration profile for Catalyst 1 (see online version for colours)

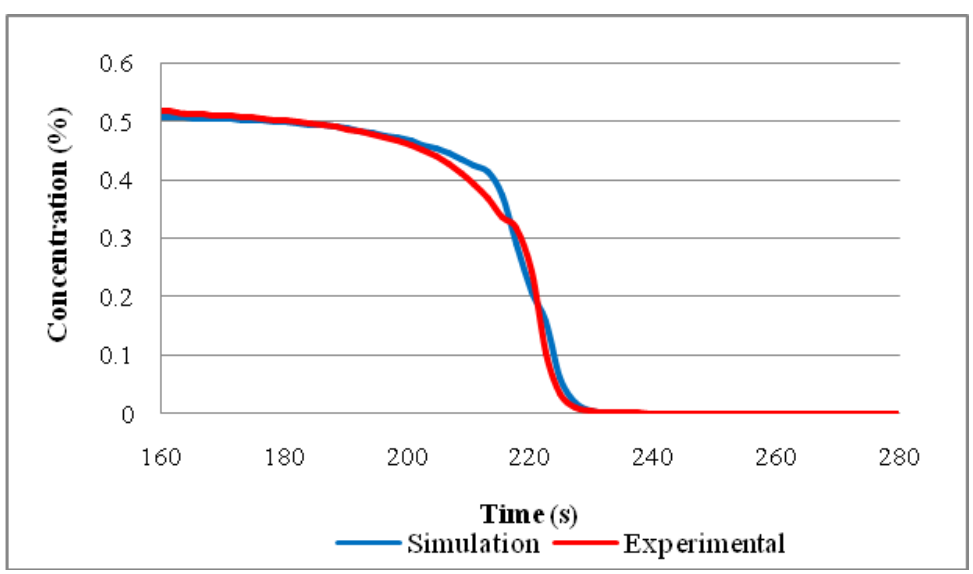

For the cored sample tests, the external heat transfer factor required to match the simulation temperature profiles to the experimental temperature profiles was the same for all samples. The value for the SIGU test simulations was 5.5, which was higher than the value of 0 required for the Labcat test simulations. This indicates that the convective heat loss that exists in the SIGU test rig is greater than in the Labcat. For the cores, the model indicates that there is a variation in the dispersion of precious metal particles across the samples, ranging from $8 \%$ to $12 \%$. The dispersion is shown to be a good indicator of catalyst activity, with the highest dispersion found to exist in the most active core (3CR) and the lowest dispersion found to exist in the least active core (4CR). Figure 16 shows the temperature profiles of the light-off ramps for each of the front core CO light-off tests, all plotted on one graph. It can be seen that the temperature profiles for all of the tests are almost identical. Therefore, it appears that only the differing dispersions of precious metal particles throughout the cores is what is changing the light-off 
temperatures. This may be due to irregularities in the thermal ageing procedure or the catalyst manufacturing processes.

Table 2 Dispersion and external heat transfer factor values required to match simulations to experimental test results

\begin{tabular}{|c|c|c|c|c|c|}
\hline \multirow{2}{*}{ Catalyst } & \multirow{2}{*}{ Test } & \multirow{2}{*}{$\begin{array}{l}\text { Dispersion } \\
\% / 100\end{array}$} & \multirow{2}{*}{$\begin{array}{l}\text { Ext heat transfer } \\
\text { factor }\end{array}$} & \multicolumn{2}{|c|}{ CO light-off temp $\left({ }^{\circ} \mathrm{C}\right)$} \\
\hline & & & & Ramp 1 & Ramp 2 \\
\hline \multirow[t]{3}{*}{1} & Full size & 0.15 & 0 & 221 & - \\
\hline & $1 \mathrm{CF}$ & 0.105 & 5.5 & 242 & 238 \\
\hline & $1 \mathrm{CR}$ & 0.085 & 5.5 & 251 & 244 \\
\hline \multirow[t]{3}{*}{2} & Full size & 0.125 & 0 & 225 & - \\
\hline & $2 \mathrm{CF}$ & 0.08 & 5.5 & 249 & 243 \\
\hline & $2 \mathrm{CR}$ & 0.1 & 5.5 & 243 & 240 \\
\hline \multirow[t]{3}{*}{3} & Full size & 0.04 & 0 & 251 & - \\
\hline & $3 \mathrm{CF}$ & 0.08 & 5.5 & 246 & 244 \\
\hline & $3 \mathrm{CR}$ & 0.12 & 5.5 & 238 & 235 \\
\hline \multirow[t]{3}{*}{4} & Full size & 0.08 & 0 & 234 & - \\
\hline & $4 \mathrm{CF}$ & 0.105 & 5.5 & 245 & 238 \\
\hline & $4 \mathrm{CR}$ & 0.085 & 5.5 & 254 & 245 \\
\hline
\end{tabular}

Figure 16 SIGU temperature profile comparison (see online version for colours)

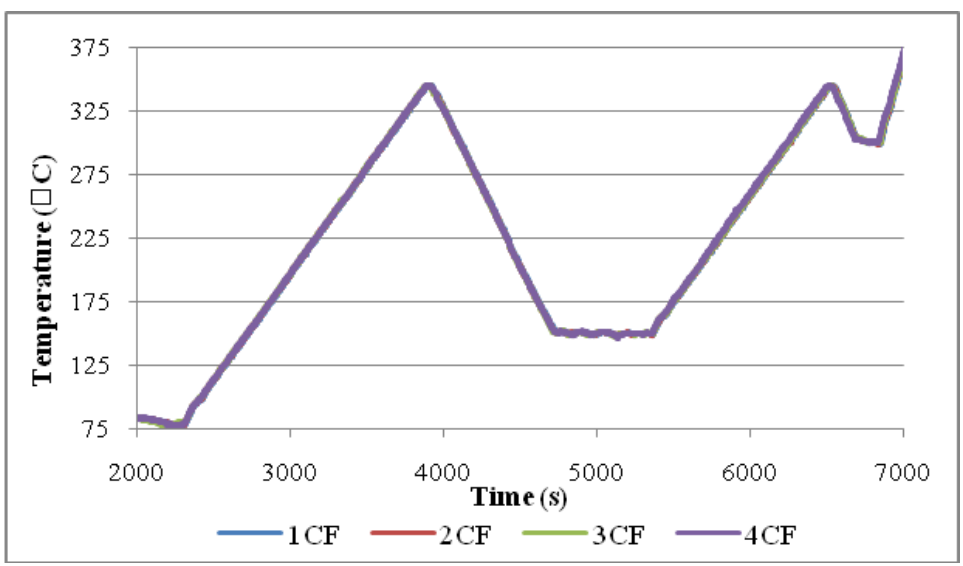


Table 3 Precious metal dispersion and external heat transfer coefficients required to match simulations to experimental light-off tests

\begin{tabular}{cccccc}
\hline \multirow{2}{*}{ Catalyst } & Test & $\begin{array}{c}\text { Dispersion } \\
\% / 100\end{array}$ & $\begin{array}{c}\text { Ext heat transfer } \\
\text { factor }\end{array}$ & \multicolumn{2}{c}{ CO light-off temp $\left({ }^{\circ} \mathrm{C}\right)$} \\
\cline { 5 - 6 } 1 & Full size & 0.105 & 5.5 & Ramp 1 & Ramp 2 \\
\hline & Full size & 0.085 & 5.5 & 223 & - \\
& $1 \mathrm{CF}$ & 0.15 & 0 & 224 & - \\
& 1CR & 0.15 & 0 & 225 & 225 \\
& Full size & 0.08 & 5.5 & 227 & 225 \\
& Full size & 0.1 & 5.5 & 227 & - \\
& 2CF & 0.125 & 0 & 229 & 229 \\
& 2CR & 0.125 & 0 & 229 & 230 \\
& Full size & 0.08 & 5.5 & 240 & - \\
& Full size & 0.12 & 5.5 & 236 & - \\
& 3CF & 0.04 & 0 & 255 & 253 \\
& 3CR & 0.04 & 0 & 253 & 253 \\
4 & Full size & 0.105 & 5.5 & 235 & - \\
& Full size & 0.085 & 5.5 & 236 & 238 \\
& 4CF & 0.08 & 0 & 238 & 238 \\
\hline
\end{tabular}

From the experimental light-off tests and initial simulations, correlation between the activity of full size bricks and cored catalyst samples is unclear; therefore, further simulations were performed. For each of the full size catalysts, simulations were performed using the heat transfer factor and precious metal dispersion values used to match the cored sample temperature and $\mathrm{CO}$ concentration profiles for simulated and experimental test results, as mentioned above. Likewise, simulations were performed for the cored catalyst samples using the heat transfer factor and precious metal dispersion values used to match the full size catalyst temperature and $\mathrm{CO}$ concentration profiles for simulation and experimental test results. For example, for Catalyst 1 the full size sample simulation was performed with the $1 \mathrm{CF}$ value of 0.105 for dispersion, and 5.5 for the heat transfer factor. The $1 \mathrm{CF}$ simulation was performed with a dispersion value of 0.15 and an external heat transfer factor of 0 . The simulation results for each of the four samples are presented in Table 3 .

With the changed values of precious metal dispersion and external heat transfer factor it can be seen that for each catalyst the simulated light-off temperature for the full size catalysts and the cores are almost identical, with the exception of Catalyst 3. For Catalysts 1,2 , and 4 , the maximum variation in light-off temperature across the samples within each catalyst is $3^{\circ} \mathrm{C}$. These results give an indication that good correlation does exist between the light-off performance of full size and cored catalyst samples, in the majority of cases. For Catalyst 3, the maximum variation is $19^{\circ} \mathrm{C}$. It is unclear why correlation does not exist in this case, but it is thought by the author that this may be due to an anomaly in the testing procedure. It does appear that the testing of cores gives results comparable to full size canned catalyst bricks, however, direct correlation is not clear without the use of a catalyst model. The testing of full size catalysts does not 
require for the brick to be destroyed by the decanning and coring processes, making this method advantageous. Also, it has been shown that there is a variation of the precious metal particle dispersion throughout a full size catalyst brick, therefore, testing of individual cores may not give a good representation of the activity of the catalyst as a whole.

\section{Conclusions}

CO activity tests performed on full size three-way catalysts and cored samples, along with simulations performed using the QUB global catalyst model, have shown that correlation between the full size and cored samples is generally good. Light-off tests have shown that variation exists between 'identical' full size bricks. The engine ageing processes were not known and test data was not available, therefore this may be the cause of the variation between full size samples. Variability was shown to exist between cores taken from the same brick, believed to be due to an uneven distribution of precious metal particles throughout the brick. Experimental analysis was not conducted to confirm the actual precious metal dispersion in this study. This may therefore be analysed in future work.

This study successfully conducts the performance testing of full size catalysts under laboratory conditions, and correlates the results to cored samples. It highlights the need for a computational catalyst model to compare the light-off performance of full size and cored catalyst samples. It also shows that the testing of full size catalyst bricks gives results comparable to those of cored samples, without the need to destroy the brick by decanning and coring.

\section{References}

Aitani, A. and Siddiqui, M. (1995) 'Review study on the catalytic control of automotive emissions', in Proceedings of the Fourth Engineering Conference, King Abdulaziz University, Jeddah, pp.369-374.

Awbi, H.B. (1998) 'Calculation of convective heat transfer coefficients of room surfaces for natural convection', Energy and Buildings, Vol. 28, No. 2, pp.219-227.

Catagen Ltd. (2013) [online] http://www.catagen.co.uk/labcat.html (accessed 23 September 2012).

Dubien, C., Schweich, D., Mabilon, G., Martin, B. and Prigent, M. (1998) 'Three-way catalytic converter modeling: fast- and slow-oxidizing hydrocarbons, inhibiting species, and steam-reforming reaction', Chemical Engineering Science, Vol. 53, No. 3, pp.471-481.

Gandhi, H.S., Graham, G.W. and McCabe, R.W. (2003) ‘Automotive exhaust catalysis', Journal of Catalysis, Vol. 216, Nos. 1-2, pp.433-442.

Harkönen, M., Kivioja, M., Lappi, P., Mannila, P., Maunula, T. and Slotte, T. (1994) 'Performance and durability of palladium only metallic three-way catalyst', International Congress \& Exposition, SAE Technical Paper Series (940935).

Harris, P.J.F. (1995) 'Growth and structure of supported metal catalyst particles', International Materials Reviews, Vol. 40, No. 3, pp.97-115.

He, Z., Shao, Q., Li, Y., Jing, Z. and Duan, Q. (2003) Study on the Aging Test Methods and the Properties of the Three-Way Catalysts, SAE Technical Paper Series (2003-01-3160).

Heck, R.M., Farrauto, R.J. and Gulati, S.T. (2002) Catalytic Air Pollution Control, Commercial Technology, 2nd ed., pp.79-94, John Wiley \& Sons, Inc., New York. 
Hietikko, M., Lassi, U., Kallinen, K., Savimaki, A., Harkonen, M., Pursiainen, J., Laitinen, R.S. and Keiski, R.L. (2004) 'Effect of ageing atmosphere on catalytic activity and textural properties of $\mathrm{Pd} / \mathrm{Rh}$ exhaust gas catalysts studied by XRD', Applied Catalysis A: General, Vol. 277, Nos. 1-2, pp.107-117.

Hughes, K.W. (2005) 'Effect of thermal mass and ageing on CO-NO $\mathrm{NO}_{\mathrm{x}}$ crossover and light-off behaviour', SAE World Congress, SAE Technical Paper Series (2005-01-1106).

Kallinen, K., Suopanki, A. and Harkonen, M. (2005) 'Laboratory scale simulation of three-way catalyst engine ageing', Catalysis Today, Vol. 100, Nos. 3-4, pp.223-228.

Lassi, U. (2003) Deactivation Correlations of Pd/Rh Three-Way Catalysts Designed for Euro IV Emission Limits, Effect of Ageing Atmosphere, Temperature and Time, $\mathrm{PhD}$ thesis, University of Oulu, Oulu, Finland.

Lopez Granados, M., Cabello Galisteo, F., Mariscal, R., Alifanti, M., Gurbani, A., Fierro, J.L.G. and Fernandez-Ruiz, A. (2006) 'Modification of three-way catalyst washcoat by ageing: a study along the longitudinal axis', Applied Surface Science, Vol. 252, No. 24, pp.8442-8450.

Martin, L., Arranz, J.L., Prieto, O., Trujillano, R., Holgado, M.J., Galan, M.A. and Rives, V. (2003) 'Simulation three-way catalyst ageing analysis of two conventional catalyst', Applied Catalysis B: Environmental, Vol. 44, No. 1, pp.41-52.

Martinez-Arias, A., Fernandez-Garcia, M., Iglesias-Juez, A., Hungria, A.B., Anderson, J.A., Conesa, J.C. and Soria, J. (2002) 'Influence of thermal sintering on the activity for $\mathrm{CO}-\mathrm{O}_{2}$ and $\mathrm{CO}-\mathrm{O}_{2}-\mathrm{NO}$ stoichiometric reactions over $\mathrm{Pd} /(\mathrm{Ce}, \mathrm{Zr}) \mathrm{O}_{\mathrm{x}} / \mathrm{Al}_{2} \mathrm{O}_{3}$ catalysts', Applied Catalysis B: Environmental, Vol. 38, No. 2, pp.151-158.

McAtee, C., McCullough, G., Douglas, R. and Glover, L. (2011) The Effect of De-Greening and Pre-Treatment on Automotive Catalyst Performance, SAE Technical Paper Series (2011-24-0188).

McCullough, G. (1997) An Investigation into the Deactivation and Characterisation of Two-Stroke Oxidation Catalysts, PhD thesis, School of Mechanical and Aerospace Engineering, Queen's University Belfast, UK.

Meyer Fernandes, D., Alcover Neto, A., Baldini Cardoso, M.J. and Zanon Zotin, F.M. (2008) 'Commercial automotive catalysis: chemical, structural and catalytic evaluation, before and after aging', Catalysis Today, Vols. 133-135, Nos. 1-4, pp.574-581.

Meyer Fernandes, D., Scofield, C.F., Neto, A.A., Baldini Cardoso, M.J. and Zanon Zotin, F.M. (2010) 'Thermal deactivation of $\mathrm{Pt} / \mathrm{Rh}$ commercial automotive catalysts', Chemical Engineering Journal, Vol. 160, No. 1, pp.85-92.

Moldovan, M., Rauch, S., Morrison, G.M., Gomez, M. and Antonia Palacios, M. (2003) 'Impact of ageing on the distribution of platinum group elements and catalyst poisoning elements in automobile catalysts', Surface And Interface Analysis, Vol. 35, No. 4, pp.354-359.

More, K.L., Kenik, E.A., Coffey, D.W., Greer, T.S., Theis, J., LaBarge, W. and Beckmeyer, R. (1997) Thermally-Induced Microstructural Changes in A Three-Way Automotive Catalyst, SAE Technical Paper Series (972905).

Oh, S.H. and Eickel, C.C. (1988) 'Effect of cerium addition on CO oxidation kinetics over alumina-supported rhodium catalysts', Journal of Catalysis, Vol. 112, No. 2, pp.543-555.

Polvinen, P., Vippola, M., Valden, M., Lepisto, T., Suopanki, A. and Harkonen, M. (2004) 'The effect of Pt-Rh synergism on the thermal stability of rhodium oxide on pure alumina and $\mathrm{Ce}-\mathrm{ZrO}_{2}$-modified alumina-supported catalysts', Journal of Catalysis, Vol. 226, No. 2, pp.372-381.

Siminson, J.R. (1988) Engineering Heat Transfer, 2nd ed., Palgrave Macmillan, Basingstoke.

Smelder, G., Jobson, E., Högberg, E., Weber, K., Lundgren, S., Romare, A. and Wirmark, G. (1991) Spatially Resolved Effects of Deactivation on Field-Aged Automotive Catalysts, SAE Technical Paper Series (910173).

Stewart, J., Douglas, R., Goguet, A. and Glover, L. (2012) 'Limitations of global kinetic parameters for automotive application', International Fuel and Lubricants Meeting and Exposition, SAE Technical Paper Series (2012-01-1638). 
Tanabe, T., Nagai, Y., Dohmae, K., Sobukawa, H. and Shinjoh, H. (2008) 'Sintering and redispersion behavior of Pt on Pt/MgO', Journal of Catalysis, Vol. 257, No. 1, pp.117-124.

Usmen, R.K., McCabe, R.W., Graham, G.W., Weber, W.H., Peters, C.R. and Gandhi, H.S. (1992) 'Techniques for analyzing thermal deactivation of automotive catalysts', International Fuels and Lubricants Meeting and Exposition, SAE Technical Paper Series (922336).

Voltz, S.E., Morgan, C.R., Liederman, D. and Jacob, S.M. (1973) 'Kinetic study of carbon monoxide and propylene oxidation on platinum catalysts', Industrial \& Engineering Chemistry Product Research and Development, Vol. 12, No. 4, pp.294-301.

Winkler, A., Ferri, D. and Hauert, R. (2010) 'Influence of ageing effects on the conversion efficiency of automotive exhaust gas catalysts', Catalysis Today, Vol. 155, Nos. 1-2, pp.140-146.

Yang, J., Tschamber, V., Habermacher, D., Garin, F. and Gilot, P. (2008) 'Effect of sintering on the catalystic activity of a Pt based catalyst for CO oxidation: experiments and modeling', Applied Catalysis B: Environmental, Vol. 83, Nos. 3-4, pp.229-239.

Zanon Zotin, F.M., Martins Gomes, O.F., Honorio de Oliveira, C., Neto, A.A. and Baldini Cardoso, M.J. (2005) 'Automotive catalyst deactivation: case studies', Catalysis Today, Vols. 107-108, pp.157-167.

Zhang, G., Hosokawa, Y. and Muraki, M. (1997) 'Thermally stable Pt/Rh catalysts', International Fuel and Lubricants Meeting \& Exposition, SAE Technical Paper Series (972909).

\section{Abbreviations}

\begin{tabular}{ll}
\hline $\mathrm{Al}_{2} \mathrm{O}_{3}$ & Alumina \\
$\mathrm{CO}$ & Carbon monoxide \\
$\mathrm{h}$ & Heat transfer coefficient $(\mathrm{W} / \mathrm{m} 2 \mathrm{~K})$ \\
$\mathrm{HC}$ & Hydrocarbon \\
$\mathrm{NOx}$ & Oxides of nitrogen \\
$\mathrm{Pd}$ & Palladium \\
$\mathrm{QUB}$ & Queen's University, Belfast \\
$\mathrm{T}_{\text {atmos }}$ & Atmospheric temperature $(\mathrm{K})$ \\
$\alpha-\mathrm{Al}_{2} \mathrm{O}_{3}$ & Alpha alumina \\
$\gamma-\mathrm{Al}_{2} \mathrm{O}_{3}$ & Gamma alumina \\
$\mathrm{B}$ & Heat transfer factor \\
$\mathrm{d}$ & Steel shell diameter $(\mathrm{m})$ \\
$\mathrm{H}_{2} \mathrm{O}$ & Water \\
$\mathrm{N}_{2}$ & Nitrogen \\
$\mathrm{O}_{2}$ & Oxygen \\
$\mathrm{Pt}_{\mathrm{Rh}}$ & Platinum \\
$\mathrm{T}_{\text {steel }}$ & Rhodium \\
$\delta-\mathrm{Al}_{2} \mathrm{O}_{3}$ & Temperature of steel shell $(\mathrm{K})$ \\
$\theta-\mathrm{Al}_{2} \mathrm{O}_{3}$ & Delta alumina \\
\hline & Theta alumina \\
\hline
\end{tabular}

